\title{
TAZKIYATUN NAFS CURRICULUM DEVELOPMENT IN JUNIOR HIGH SCHOOL (Analysis of Concepts Tazkiyatun Nafs by Ahmad Anas Karzon and its Implementation in Junior High School)
}

\author{
Hisan Mursalin \\ STIBA Ar Raayah Sukabumi, Indonesia \\ hisanmursalin@gmail.com
}

\begin{abstract}
Islam considers that education is not only as a process of transfer and transformation of knowledge naturally, but also a mandate that aims to make students to be a person who has divine personality (robbani), good moral and makes his life be more qualified due to the increase of spirit of faith in his soul; worthwhile both in the world and in the hereafter for him. Purification of soul or Tazkiyatun nafs is very important in the life of a human being. The soul determines whether an action is good or bad because a clean soul will produce taintless behavior while a bad soul will produce bad behavior and morals. This is certainly related to the tazkiyatun nafs concepts which have been explained by the scholars in which the concept of purification of soul is a spiritual need in the form of the teaching of din (Islam), tarbiyah, and tazkiyah for the soul. The human orientation today that prioritizes material does not guarantee the happiness of life. Facts have spoken that life's confusion and mental drought have mushroomed everywhere. The purpose of applying the concept of tazkiyatun nafs to the education is to lead the formation of a noble Muslim figure, with the same educational goals; human perfection in terms of taqarrub (to closer) to Allah, and happiness in the world and the hereafter. While the difference is when education is oftentimes merely taught without any guidance and direction in carrying out the morality or worship taught. Therefore, current education should do the soul purification at first so as the worship performed imprints on human heart and behavior.The focus of the problem in this study is to develop the Tazkiyatun Nafs curriculum appropriate with the age of junior high school students. Development of the curriculum is focused on developing goals, materials, methods, learning techniques, evaluation techniques, patterns of interaction and its implementation in everyday life. In conducting this research, the writer applied field study type since the data needed to compile scientific work was obtained from the research field. The research used a qualitative approach aimed at understanding social phenomena from the view of or perspective of participants. The Participants were those who were invited to interview, observed, asked to provide data, opinions, thoughts and perceptions. In terms of the presentation of material was descriptive analysis because this study attempted to sharpen the analysis of the full description related to
\end{abstract}


the concept of tazkiyatun nafs which was then implemented to junior high school students. The result of the observation about the implementation of the tazkiyatun nafs curriculum at Darussofa IT Junior High School showed that the implementation of curriculum in everyday life needs to be taken into account by fostering the inner piece experienced by students so that a sense of being watched by Allāh will be grown.

Keyword: 'tazkiyatunnafs, ahmad anas karzon, education.

\section{INTRODUCTION}

\section{A. Background}

The purpose of Islamic education is not a fixed and static object. ${ }^{1}$ But it is an apostolic vision of the prophets, from the prophet Adam 'alahissalam to the Prophet Muhammad, namely to build a human life that is obedient and submissive to Allah, ${ }^{2}$, Private Fostering Muslims to be strong-minded cadres and prepared into Islamic society, foster humanitarian aspects of managing and safeguarding the welfare of the universe. ${ }^{3}$

Hasan Langgulung says in his book that the aim of Islamic education should be able to accommodate the three main functions of religion, the spiritual function related to aqidah with faith, psychological functions related to the behavior of an individual including the moral values that elevate man to a greater degree perfect and social functions related to the rules that connect people to one another human being or society. ${ }^{4}$

To make people capable of running three religious functions well, someone must have a clean heart (sacred). They need for the process of cleaning the soul (tazkiyat al-nafs) so that their heart can be purified. Since the heart is the only organ that becomes an influence on all organs of the body. The Prophet said, which means "true adam child's body contained a piece of flesh. When it was good, the whole body, it is the heart. ${ }^{5}$

Islam is a religion revealed by God and brought by Prophet Muhammad for the benefit of mankind and Hereafter, Islam governs all aspects of human life from the smallest to the largest, from the simplest to the most complex of human even wake up until the bed

\footnotetext{
${ }^{1}$ Zakiya Degrees, Islamic Education, Jakarta: Earth Literacy, 1991, p. 10.

${ }^{2}$ Abuddin Nata, Pendidiakn Islamic Philosophy, Jakarta: Style Media Primary. 2005, p. 30.

${ }^{3}$ Abudin Nata, Philosophy of Islamic Education, Jakarta: Logos Discourse Studies. 1997, p. 11.

${ }^{4}$ Ibid, p. 46

${ }^{5}$ Al-Ghazali, Ihya Summary 'Ulumuddin, translation Zeid Al-Hamid Hussein, Jakarta: Pustaka Amani, 2007, p, 215.
} 
again, Islam is a system in which there are aspects of the teachings of belief (faith) law (legal aspects) and nature (inner aspect). Apostles and Prophets sent by God revelation and purify the human soul, as contained in his Word the Qur'an Surat ash-Shams: 9

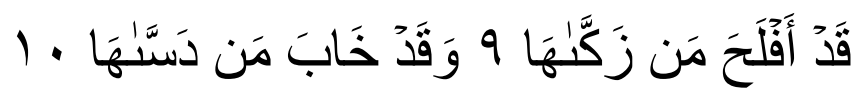

indeed successful who purifies the soul, and actually lost the person who contaminated

Read the paragraph above, it is clear that purify the soul or nafs Tazkiyatun very important in the life of a human being. Soul specify an action is good or bad action or behavior, for the purified soul will result in good behavior or character and a poor soul would result in behavior or bad character.

Islam regards education is not only a process of transfer and transformation of knowledge naturally, but also is a mandate that aims to make his protege into someone's personality Robbani, has a good character and makes their life more qualified because the increase of faith in the soul of the child, useful for them in this world and in the hereafter.

Of course all of this is related to the concepts tazkiyatun nafs been described by scholars in which the concept of purification of the soul is a form of education for the spiritual needs of din (Islam), tarbiyah, and Tazkiyah for the soul. Orientation man today that emphasizes the material did not ensure happiness in life. The fact has been talk that the turmoil of life and soul of drought happened everywhere.

The purpose of applying the concept tazkiyatun nafs in education is directed to the formation of a noble individual Muslim. With the same educational goal of human perfection in terms taqarrub (closer) to Allah, and happiness of the world and the hereafter. While the difference is when education is taught often only given away without supervision and guidance in implementing taught morals or worship. Therefore, the current education should make purification of the soul first, so worship performed may imprint on the hearts and human behavior.

So every human being to do the cleaning of the soul, so close to the creator. Tazkiyatun nafs is needed to foster the spiritual in human hearts, survivors in the world and happy in the afterlife, eternal happiness, shining and pure hearts.

Tazkiyatun nafsis one of the Islamic sciences that have a special attraction to continuously studied in greater depth and comprehensively. Furthermore Tazkiyatun nafs 


\section{Mursalin}

will bring people to the degree ulul albab, namely human "Zikr and at the same time thinking, thinking and simultaneously Zikr." It needs to be studied and understood by prospective educators who will nurture and guide learners, so that they are in transforming science and his stint as education refers and lead to that goal.

In that role, the concept of Nafs Tazkiyatun can achieve a good education system through an educational plan called the curriculum. In tazkiyatun nafs implementsinya enrichment curriculum can help students to better khusyu and interpret all of the learning process.

\section{B. Restrictions and Formulation Problems}

Description of the background of the above problems, the author will limit the scope of the discussion into some formulation of the problem. The limitation of scope in this discussion, can be formulated as follows:

1. How the Tazkiyatun nafs concept by Ahmad Anas Karzon for learners?

2. How the Tazkiyatun nafs Education Implementation in SMP IT Darussofa?

3. How the process of Curriculum Development Tazkiyatun nafs in Junior High School?

\section{Research purposes}

From the formulation of the above problems, it is known the purpose of research in writing this paper, namely;

1. To know the concept of Tazkiyatun Nafs applied to learners.

2. Analyze the implementation of the curriculum Tazkiyatun nafs in Junior High School.

3. To develop a curriculum of Tazkiyatun Nafs in junior high school.

\section{Benefits of research}

1. Academic benefits

a. Is expected to provide input for curriculum Tazkiyatun nafs especially junior high school level

b. The results of this study are also expected to provide additional information or comparison to other researchers on similar issues.

2. Practical benefits

a. Broaden the curriculum of tazkiyatun nafs researcher Dr. Anas Ahmad Karzon and the 'alim ulama

Adding to contribute to advanced research, which is expected to contribute to the development of more comprehensive Islamic thought.Metode Penelitian 
TAZKIYATUN NAFS CURRICULUM DEVELOPMENT IN JUNIOR HIGH SCHOOL (Analysis of Concepts Tazkiyatun Nafs by Ahmad Anas Karzon and its Implementation in Junior High School)

\section{RESEARCH METHOD}

\section{A. Research approach}

In conducting this study, the authors use this type of field study because the data needed to prepare scientific papers from the field. As this study used a qualitative approach aimed at understanding the social phenomena of the angle or perspective participants. Participants are those who are invited to interview, observation, were asked to provide data, opinions, thoughts and perceptions. ${ }^{6}$ Then in terms of the presentation of this material is descriptive analysis, because this study tried to sharpen the analysis of the full description of related concepts tazkiyatun nafs then implemented to learners junior high school level.

\section{B. Data collection technique}

To obtain the necessary data in this research data collection techniques as follows:

1. Questionnaire or Questionnaire

Researchers scale distributed questionnaire Likert to 31 students of SMP IT Darussofa, then processing with SPSS program to determine the percentage of research results.

2. Documentation

Documentation is a method of assessing and processing the data of the documents that already exists and supports research data. This technique is used to collect data from documents and archives about the reality of learning in junior IT tazkiyatun Darussofa nafs.

3. Interview

The interview as a meeting of two or more people to exchange information and ideas through questions and answers, so it can be constructed meaning within a topic. Researchers prepare research instruments in the form of written questions to be asked, and noted what was found by the informants about the obstacles, criticisms and suggestions in the curriculum tazkiyatun nafs.

4. Observation

\footnotetext{
${ }^{6}$ Nana Syaodih Sukmadinata, Educational Research Methods, Bandung: PT Young Rosdakarya, 2010, p. 94.
} 
Observation is a data collection technique for observing human behavior, work processes, and the phenomena of nature, and the respondent. In this study, researchers observed directly and indirectly to find the facts on the ground. The instruments used by researchers is non-participants and participant observation structured.

\section{Data analysis technique}

In this study, analysis of the data used using techniques Analysis Interactive Model of Miles and Huberman, steps in activity data analysis described in step - step study of data collection (data collection), the reduction of the data (data reduction), presentation of data ( Data display), and conclusion or verification (conclutions)

\section{DISCUSSION}

\section{A. Understanding Tazkiyatun nafs}

According to Anas Ahmad Karzon, tazkiyatun nafs is to purify the soul of a bad trend and sin and develop good character in it that can enforce istiqomahnya and reached the degree of ihsan. ${ }^{7}$

Tazkiyah etymologically has two meanings, namely purification and growth. Similarly, the meaning of the term. Zakiyyatun nafsi means of purification (tathahur) people from all penyeakit and disability, realize (tahaquq) various maqam him, and make asthma 'and the nature of God as the moral (takhaluq). So tazkiyyah is tathahur, tahaquq and takhaluq. ${ }^{8}$

Tazkiyatun nafs is the process of purification of the soul that do continue - constantly by a Muslim to draw closer to God 此, ${ }^{9}$ This effort in accordance with the Word of God Al - Qur'an Surat ash-Shams [91]: 10-9

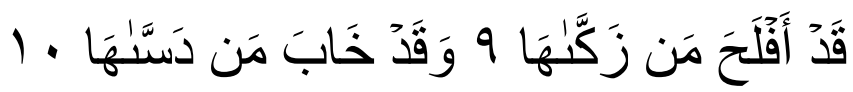

Indeed, fortunately for those who purify ijwa it, and be unfortunate person who contaminated

\footnotetext{
${ }^{7}$ Anas Ahmad Karzon, Tazkiyatun nafs, East Jakarta: Akbar Media, 2016, p. 11

${ }^{8}$ Ibn Qayyim al-Jauziah, tazkikiyatun nafs, Solo: libraries Arafah, 2001, p 26

${ }^{9}$ Abdul Kholiq, Guidance and Counseling Islam, Yogyakarta: Temple Library, 2009, p 36
} 
It can be concluded that tazkiyyatun nafs is a process of purification of the soul which is done continuously - in order to reduce the tendency of being negative and positive trends in order to draw closer to God 紧,

And in the next section we will describe a strong bond between worship - worship and means - the practical means to effect purification shar'i Soul and building the perfect Islamic personalities especially for learners. Here the concept of tazkiyatun nafs Anas Ahmad Karzon which will be described in the next section deals with the implementation of

1. Useful Science in Tazkiyatun nafs

2. Amal Saleh in Tazkiyatun nafs

3. muhasabah and Penance in Tazkiyatun nafs

4. Friends with People - People Salih and Reflecting on the circumstances - the circumstances in Tazkiyatun They nafs

\section{B. Tazkiyatun concept Anas Ahmad Karzon nafs and its Implementation in SMP IT Darussofa}

Dr. Anas Ahmad Karzon He was born in Allepo, Suriyah in 1958. He completed doctoral studies at the Faculty of Shariah at Umm al-Qura University in Makkah Saudi Arabiyah, in writing his dissertation he presents article titled Manhaj Al - Islami Fii Tazkiyatin nafs, he is a lecturer and an expert Humanism and Islamic Psychology at the University of Umm Al-Qura Makkah Al - Mukarramah and he is Chairman of the International Agency for Quran memorizers, he has written more than 25 books.

On this occasion the authors take the primary data from his book with the title Manhaj $\mathrm{Al}$ - Islami Fii Tazkiyatin nafs, which was then translated by Emiel Threeska and published by Akbar Media. In his work, he explained the concept Tazkiyatun useful nafs through Science, Amal Saleh, Muhabah, repentance and friendship with the pious. Following the exposure draft Anas Ahmad Karzon Tazkiyatun nafs.

Tahfidz Pesantren Al - Qur'an Darussofa stand at the end of 2014, as a place of education development in the education of the nation concentration Qur'an, memorize, study and practice it, plus the knowledge of other religious education to equip students trained scientific treasures. Pesantren is composed of two levels and high school education. The overall number of students in 2019 was 67 students. Consisting of 37 junior high school 


\section{Mursalin}

students and 30 high school students. In the present study, we will examine the implementation of the nafs tazkiyatun education junior high school students.

Education Tazkiyatun nafs in junior IT Darussofa, consisting of two objectives, the general purpose led to the knowledge of the importance of clean soul by training the spirit of students to be closer to his Lord through programs in schools as well as assessment of the book of monotheism, the book tazkiyatun nafs, dhikr morning and evening activities, activities Tahfidz Al - Qur'an, educational seminars and activities. As for its specific purpose is, the inner peace that is felt the students so that the resulting flavors are supervised by Allāh 䊼.

Indicators of success in this study refers to the concept of the nafs tazkiyatun Anas Ahmad karzon shown by, accompanied by the First Science righteous deeds can be seen from the Change BehaviorChanges in attitude and inner tranquility Second Amal Saleh could be seen by students devout soul in worship, which in accompanied by an improvement in the quality and quantity of the worship of God, timely in conducting worship obligatory and always keep things in sunahkan. third Muhasabahand Repentance seen from a change in attitude, waking up in the third of the night to bermuhasabah and repent and obey the rules of boarding. Fourth friends with pious people by creating a conducive environment and support each other in goodness.

This success can be achieved by all students who are determined by factors of which there is an understanding of the theory, practice will be the worship practices and most importantly, is there on the probity of the students.

The following will describe research results tazkiyatun concept nafs Ahmad Anas Karzon and Implentasinya in junior IT Darussofa with Likert scale questionnaire distributed to 31 students of SMP IT Darussofa.

Answer each item instrument Likert scale has a gradation from very positive to very negative, which is the form of words among others: Strongly Agree (SS) Agree (S) Agree Less agree (KS) Disagree (TS), and Strongly Disagree (STS ).

Explanation of Results of research questionnaire tazkiyatun concept nafs and its Implementation in SMP IT Darussofa is as follows,

1. Implementation Science is Beneficial in Tazkiyatun nafs 
Tazkiyatun concept nafs Ahmad Anas Karzon in Science useful to realize that the holy spirit is a science that can bring souls to God 悠, Adding to the fear of him, and to motivate yourself to do righteous deeds. The most important science is the science syar'i (religion). After science shar'ie then other sciences that encourage people to reflect on a variety of creatures and feel the power of God and His creation. ${ }^{10}$

In order to fulfill its role of science in the process of purification of the Soul, then science must meet the following two conditions, first, that science must be accompanied by good deeds done outright simply because Allah Ta'ala, and uphold the adab-adab unusual for a teacher and students. Second, a Muslim should keep away sophist and disputes in matters of science.

a) Science is accompanied by Amal Sholeh

Useful science is the science which was followed by a charity and make noble owners and has perfect manners, hold fast to the Qur'an and Sunnah, and has sincere intentions only because of God. Thus, the science that will produce the expected results for the purification of the soul.

After doing research with the Likert scale questionnaire distributed to 31 students of SMP IT Darussofa, in its implementation, junior IT Darussofa teach the importance of science that accompanied Amal Saleh with a percentage of $93.5 \%$ response and 6.5\% Strongly Agree Agree Answering.

In the statement "Science is beneficial not affect Morals and manners I" with a percentage of answer Strongly disagree $48.4 \%$ Disagree $45.2 \%$ and $6.5 \%$ less agree. This means that the students are aware of the increase in morals and manners with useful knowledge.

In the statement "I do not feel the inner tranquil retreat when studying" This is a negative statement so that the students answered, Strongly disagree $41.9 \%$ Disagree 25.8\% Agree 22.6\% Less, And Agree 9.7\%. Ahmad Anas Karzon mention that in the Science useful to realize that the holy spirit is a science that can bring souls to God

\footnotetext{
${ }^{10}$ Ibid, p 63
} 
statement "I do not feel the inner tranquil retreat when seeking knowledge" means the students feel calm and purification of the soul in the study.

In the statement "I feel a change in attitude after learning in Darussofa" Percentage response was Strongly agree Agree $71 \%$ and $29 \%$. This proves that the process of learning not only the transfer and transformation of natural science, but also a mandate which aims to turn into someone's protégé personality Rabbani.

In the statement "My teacher never taught about the etiquette of" the percentage response was Strongly Disagree Disagree $80.6 \%$ and 19.4. This means that the implementation of teaching manners to students has been done.

In the statement "I am respectful and obedient to my teacher" percentage response was Strongly agree Agree $48.4 \%$ and $51.6 \%$. Practice against the morals and manners have been done in Darussofa.

In a statement the "Regulations on Darussofa make me noble" percentage response was Strongly agree Agree $61.3 \%$ and $38.7 \%$. In this statement the students agreed to the effectiveness of the rules or regulations that are applied in darussofa therefore contributes to the character and adabnya.

In the statement "I always practice the knowledge I can" prensentase response was Strongly agree 25.8\% Agree 61.3\%, and 12.9\% less agree. Practice of the science in the can is essential, so the average - average response would agree this statement.

From the questionnaire that was answered by the students, it can be concluded Darussofa teachers emphasize to the students to continue the science that has been the failure by that form of noble character and have impeccable manners. By providing teaching and rule of order in the school so that the students can get familiar with the morals and manners are learned and implemented in daily life today.

b) Steer clear of sophist and disputes in matters of science.

Steer clear of debate and squabbling in the Scientific Issues, argue and fight in issues of science can be hardened and prevents a person from getting the results of science. The second condition that must exist in order to be able to fulfill its role 
of science to purify the soul and improving its condition, is to distance themselves from contention, debate, and disagreement on matters of science.

In the implementation, junior IT Darussofa teach all students to always respect each other, and away from the insular nature of the science of religion, emphasizing the culture, and explain about the extent of religious knowledge of Islam.

In the statement "Religion of Islam only one schools the" percentage of response was $61.3 \%$ strongly disagree, disagree $19.4 \%$, and $19.4 \%$ less agree. This means that the students have been taught about the extent of Islamic Studies that do not arise insular nature when interacting with other fellow Muslims and this is validated by the statement "fellow Muslim Brotherhood is very important" percentage response was Strongly Agree Agree 93.5\% and 6.5\%.

2. Implementation Amal Saleh in Tazkiyatun nafs

Beneficial knowledge and good deeds have a very strong attachment. Studies that did not bear a charity and does not motivate charity bukanlan useful knowledge. While charities that are not based on syar'i science and do not follow the Qur'an and Sunnah also will not give perfection to the culprit.

Many verses of the Qur'an and the hadith of the Prophet which confirms the extreme importance of good deeds soul purification, and increasing at a high position and great Maqaam, and realize the happiness in the world and the hereafter. Allah Almighty has said, in Al - Qur'an Surah Fatir [35]: 10

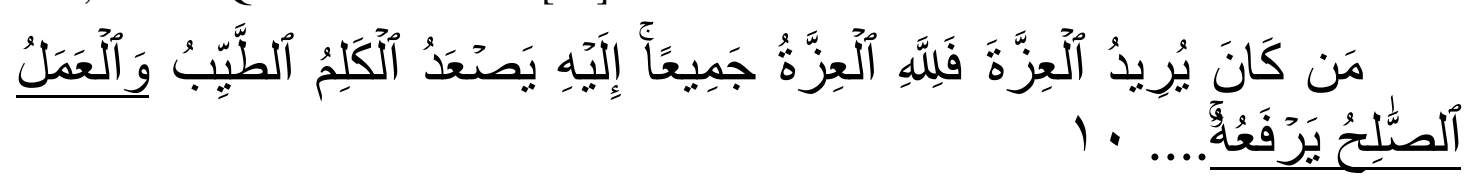

Anyone who wants glory, then all glory belongs to God. Dedicated to Him good words and good deeds, then he will raise it.

Abu Malik al-Ash'ari said that the Messenger has said, "Cleanliness is part of faith. 'Alhamdulillah' meet the scales. 'SubhaanAllah and' Thank God ', both meet between heaven and earth. Prayer is light, charity is descriptive, patience is light, the Qur'an is a proof for you or you. Each man set off in the morning then trades his soul. then there were freed, some are destroyed. " (Muslim) 
This hadith shows that good deeds can purify the soul and clean it, and that every human being, no one walked toward the destruction or salvation. So anybody walking in obedience to God, then he has to sell himself to God and release him from his doom. Anyone who walks in the sinners to God, then he has to sell himself with humility passions and harm themselves by sin would have faced the wrath and punishment of God.

The concept Tazkiyatun nafs Ahmad Anas Karzon in worship shall example of prayer, when a servant pray with passion and love, feel the whisper - whisper to God, and humbled himself to - him, his prayer will have a spiritual power that can give strength spirit and soul,

Devotions sunnah is one of the great goodness door as a means to race to obedience and a major favor. With this sunnah worship Allah exalt his servants to be closer to Him and obtain His mercy and good pleasure, and purify their souls and turn their hearts.

When a servant immersed in remembrance, prayer, and read and listen to the recitation of the Qur'an, as well as the use of time-a prime time for evening prayer, earnestly for humility ', reflect and bring the heart, then it is a moment we are closest to God 此, It's very big influence in the process of purification of the soul, and increase the degree of perfection.

In the implementation, junior IT Darussofa has taught about the importance of righteous deeds for the purification of the soul and very attentive to deeds - deeds sunnah on all students, such as fasting sunnah, Qiyamulail that the students in the compulsory to get up at 3:30, and most important is the activity of memorizing $\mathrm{Al}$ Qur'an which is the most important remembrance, program Tahfidz Al - Qur'an is the most superior program in junior IT Darussofa. carried out every day, and worship other Sunnah worship to strengthen the faith and purify the soul. In the questionnaire that was distributed and answered by the students, then the result can be seen as follows.

In the statement "Amal Saleh is essential for cleansing the soul" the answer is very amenable percentage of $74.2 \%, 19.4 \%$ agree, disagree $6.5 \%$. This means that students know that peace of mind can be achieved by extending the shloleh Amal, is attested by the next pernytaan, "I feel inner peace when worship" the percentage response was Strongly agree $71 \%$ Agree $25.8 \%$ and $3.2 \%$ Less seutuju. 
In the statement "I prefer to come to the mosque when the call to prayer from the prior azan" percentage response was Strongly agree 6.5\% Agree 29\%, Less agree $35.5 \%, 22.6 \%$ Disagree and Strongly disagree $62 \%$. This statement is a negative statement so that the average response expressed less agreed as an indicator of success in this study statedstudents devout soul in worship, which in accompanied by an improvement in the quality and quantity of the worship of God, timely in conducting worship obligatory and always keep things in sunahkan.

In the statement "My teacher always taught about the sincerity" percentage response was Strongly agree Agree 51.6\% and 48.4\%. Implementation of teaching about the nature of sincerity has been done by the IT Darussofa junior faculty.

In a statement the "Regulations on Darussofa made my forced" the percentage response was Strongly disagree $32.3 \%$ Disagree 48.4\%, $16.1 \%$ less agree, and agree $3.2 \%$. Average - Average response states do not agree, because the rules in darussofa regularly educate the students to learn.

In the statement "I always wake up before dawn call to prayer rang out" the percentage response was Strongly agree $74.2 \%$ Agree $19.4 \%$ and $6.4 \%$ less agree. As mentioned at the outset that the rules require that each santrinya wake darussofa 03.30 to prayer Qiyamullail and memorize Al - Qur'an.

In the statement "I do not feel calm when mengahafal Al - Qur'an" percentage response was Strongly disagree $61.3 \%, 32.3 \%$ disagree and agree $6.4 \%$. This means that the students feel at ease with the process of memorizing Al - Qur'an as read, memorize and study the Al - Qur'an is the main remembrance. In the statement "I learned a lot in practice sunnah Darussofa" percentage answer is really quite agree Agree $67.7 \%$ and $32.3 \%$.

According to Ahmad Anas Karzon, Agar sunnah worship can play a major role in the process of purification of the soul, then a Muslim must carry out two basic requirements, namely: First, disobedience Working Habits Leaving The second is to multiply the remembrance of Allah

In the implementation, junior IT Darussofa very attentive to each students to continue to comply with the rules and keep the students from maksyiat, with efforts to 
provide an understanding of the danger of maksyiat and provide activities - positive activities that can purify the soul afraid of sin and bring awareness because they are supervised by God 能,

In the statement "Maksiyat makes my heart calm dirty and not" the answer is very amenable percentage of $58.1 \%$ Agree $38.7 \%$, and $3.2 \%$ less agree. And In the statement of "Dhikr morning and evening make myself awake from maksiyat" The answer is very amenable percentage of $64.5 \%$ and $35.5 \%$ disagree.

The conclusion implementation righteous deeds in tazkiyatun nafs in junior IT Darussofa accordance with Indicators tazkiyatun nafs in charity sholeh SOUL students devout in worship, which is accompanied by an increase in the quality and quantity of the worship of God, timely in conducting worship obligatory and always keeping things - things in sunahkan. Average presentse showed a positive thing.

3. Implementation muhasabah and Penance in Tazkiyatun nafs

One of the best ways for a servant to increase the degree of purification itself is by introspection (muhasabah) and pay attention to good deeds he had done. If he finds good deeds, then he would praise God for and determined to increase his good deeds. But if he finds the opposite, then he will be very sorry and repent with true repentance.

So the first step that must be done is muhaasabah, and then converted correctly. Penance is the fruit and the result of this muhaasabah process.

Junior IT Darussofa provide the opportunity for his students to always seclusion with God此in the last third of the night with a mandatory program to establish qiyamul wake Lail. So the opportunity to bermuhasabah and Repentance can be done in the last third of the night.

Achievement of an education should be measured and the idea in this study provide daily muhasabah books for the students good deeds - deeds mandatory or sunnah, with the aim of scoring generations Istiqomah in goodness.

After doing research with the Likert scale questionnaire distributed to 31 students of SMP IT Darussofa, In the statement "Muhasabah (introspection) increases the degree of purification of the soul" the answer is very amenable percentage of $45.2 \%, 48.4 \%$ agree, less agree $6.5 \%$, Dominant students will agree this concept and are less amenable only 2 out of 31 students were given a questionnaire items. 
In the statement "The school provides for punishment for students who violate" the percentage response was Strongly agree $41.9 \%, 45.2 \%$ agree, less agree 3.2\% Disagree $6.5 \%$ Strongly disagree $3.2 \%$. The answer is quite varied but the dominant say agree because the students will be a deterrent punishment and bermuhasabah (introspection) on what he is doing.

In the statement "Schools provide compulsory practice or sunnah books to always mengintospeksi themselves" the percentage response was Strongly agree $25.8 \%, 58.1 \%$ agree, less agree $16.1 \%$. But this has not been done in SMP IT Darussofa, so that a good input for the school.

In the statement "I always bermuhasabah and repentance in the last third of the night" percentage response was Strongly agree 19.4\%, 51.6\% agree and 29\% disagree. As mentioned earlier that schools provide time for the students wake up in the last third of the night to do qiyamulail and muhasabah for the cleansing of his soul because of the statement "Repentance soothe my heart" the answer is very amenable percentage of 77.4\% and 22.6 Agree. So muhasabah, and repentance is a means of the students for the purification of the soul.

4. Implementation of Friends with People - People Saleh in Tazkiyatun nafs

Tazkiyatun nafs related to the goal of human life, namely to get happiness both in terms of physical and spiritual. Happiness is the perfection of the soul, and the perfection of the soul itself depending on the purity. As for blocking the perfection of the soul is a stain on torehkan ugly traits. It's all related to the environment and friends., This has been done in darussofa,the statement "The school makes the students devout in worship" the answer is very amenable percentage of $48.4 \%$ and $51.6 \%$ disagree. And In the statement "I feel comfortable in darussofa for friend - my friend was a devout" answer percentage is $54.8 \%$ strongly agree, agree $41.9 \% 3.2 \%$ Less agree.

Keeping in touch with the pious and sit with him, as well as reflecting on the circumstances and their way of life will pump one becomes pious and righteous. By doing so, one would rise in rank towards perfection, got the stronghold themselves from a variety of mental illnesses and the cunning of Satan.In the statement "I prefer to hang out with students who constantly break the rules than get together with who abide by 
the rules boarding" percentage response was Strongly disagree 48.4\% Disagree 29\%, $19.4 \%$ less agreed, and agreed $3.2 \%$. Average - Average answers did not agree because hanging out with the pious will impact previously mentioned suit is supported by In the statement "Friends influence of piety and purity of soul I" percentage answer is $64.5 \%$ strongly agree, 29\% disagree and 6.4\% less agreed, and the statement "I am motivated by a pious friend who" strongly agreed percentage of the answer is 54 , Disagree $8 \%$ and $45.1 \%$.

In the statement "The school makes the students devout in worship" the answer is very amenable percentage of $48.4 \%$ and $51.6 \%$ disagree. This statement is evidence that students feel the change after studying in darussofa.

In the implementation, junior IT Darussofa trying to create a good environment and scored generation - a generation that berakhlakul karimah and have manners are high, of course all of it consists of several stages tekait material taught, methods used, evaluation techniques are implemented, and procedures orderly schools that make the environment conducive to learning and getting along well.

In conclusion, the implementation of education Tazkiyatun nafs in junior IT Darussofa that has generally been implementing the objectives of education tazkiyatun nafs has dicanankan by the school namely Education Tazkiyatun nafs in junior IT Darussofa, consisting of two objectives, the general purpose led to the knowledge of the importance of the soul clean and its special purpose is, the inner peace that is felt the students so that the resulting flavors are supervised by Allāh 齿.

Indicators of success in the study referred to the concept of the nafs tazkiyatun Anas Ahmad karzon shown by, accompanied by the First Science righteous deeds can be seen from the Change BehaviorChanges in attitude and inner tranquility in this case in general the students have shown a change from the initial entry into a boarding school until now IT Darussofa junior students. Second Amal Saleh could be seen by students devout soul in worship, which inaccompanied by an improvement in the quality and quantity of the worship of God, timely in conducting worship obligatory and always keep things in sunahkan. In this case a significant change to the better, and a few suggestions to make the book daily practice so that students can intstropeksi and focused in doing deeds obligatory or sunnah.third Muhasabahand Repentance seen from a change in attitude, waking up in 
the third of the night to bermuhasabah and repent and obey the rules of boarding. As the results of the questionnaire showed good results and has been accomplished. Fourth friends with pious people by creating a conducive environment and support each other in goodness. As in the questionnaire that was distributed to 31 students, the results obtained are very good and have done from dicanankan success indicators.

\section{Nafs Tazkiyatun Curriculum Development in Junior High School}

In this study the enrichment curriculum development tazkiyatun nafs refers to competencies in the curriculum syllabus 2013 junior class 7,8, and 9 revised edition 2017 subject of Islamic education and Budi Character. Its development will be associated with the concept of the nafs Tazkiyatun Anas Ahmad Karzon, following the syllabus and curriculum development tazkiyatun enrichment nafs.

\begin{tabular}{|c|c|c|}
\hline & & Class VII-IX \\
\hline \multirow[b]{2}{*}{ Al-Qur'an } & Competence & $\begin{array}{l}\text { Read, memorize, and present live link } \\
\text { between attitudes to the values contained } \\
\text { in the selected verses. }\end{array}$ \\
\hline & $\begin{array}{l}\text { Tazkiyatun } \\
\text { concept nafs } \\
\text { Ahmad karzon }\end{array}$ & $\begin{array}{l}\text { Understanding Virtue read, memorize, } \\
\text { study Al - Qur'an and understand the role } \\
\text { of Al - Qur'an in the purification of the } \\
\text { soul. }{ }^{11}\end{array}$ \\
\hline \multirow[b]{2}{*}{ aqidah } & Competence & $\begin{array}{l}\text { Convinced, appreciate, understand and } \\
\text { present examples of behavior that reflect } \\
\text { the teachings of the pillars of the Faith. }\end{array}$ \\
\hline & $\begin{array}{l}\text { Tazkiyatun } \\
\text { concept nafs } \\
\text { Ahmad karzon }\end{array}$ & $\begin{array}{l}\text { Understanding the building foundation firm } \\
\text { and good soul is the true servitude to Allah, } \\
\text { faith in Him and the religion of truth that He } \\
\text { ridai for servant - his servant. }{ }^{12}\end{array}$ \\
\hline
\end{tabular}

\footnotetext{
${ }^{11}$ Ibid, p. 133

${ }^{12}$ Ibid, p. 25
} 


\section{Mursalin}

\begin{tabular}{|c|c|c|}
\hline \multirow[t]{2}{*}{ morals } & Competence & $\begin{array}{l}\text { Convinced, appreciate, understand the } \\
\text { meaning and presents examples of } \\
\text { commendable behaviors and act truthfully. }\end{array}$ \\
\hline & $\begin{array}{l}\text { Tazkiyatun } \\
\text { concept nafs } \\
\text { Ahmad karzon }\end{array}$ & $\begin{array}{l}\text { Mutual love for God, advise one another in } \\
\text { goodness, be a good example }\end{array}$ \\
\hline \multirow[t]{2}{*}{ Fiqh } & Competence & $\begin{array}{l}\text { Running, appreciate, understand and } \\
\text { practice the procedures for presenting and } \\
\text { purification from impurity of small and } \\
\text { large impurity, the obligatory prayers in } \\
\text { congregation, prayers Friday, an Islamic } \\
\text { prayer in congregation and munfarid, } \\
\text { prostration of gratitude, prostration } \\
\text { recitations, prostration for forgetfulness, } \\
\text { fasting obligatory and sunna, food and } \\
\text { drinks were lawful and unlawful, zakat, } \\
\text { Hajj and Umrah, the slaughter of animals, } \\
\text { sacrifices and aqiqah accordance with the } \\
\text { provisions of shari'ah. }\end{array}$ \\
\hline & $\begin{array}{l}\text { Tazkiyatun } \\
\text { concept nafs } \\
\text { Ahmad karzon }\end{array}$ & $\begin{array}{l}\text { Understanding the importance of Ikhlash } \\
\text { and Ittiba '(follow) the Prophet } \\
\text { Worship Mahdoh. Understanding the } \\
\text { urgency of Worship and influence in the } \\
\text { purification of the soul. }\end{array}$ \\
\hline
\end{tabular}

${ }^{13}$ Ibid, p. 185 
TAZKIYATUN NAFS CURRICULUM DEVELOPMENT IN JUNIOR HIGH SCHOOL (Analysis of Concepts Tazkiyatun Nafs by Ahmad Anas Karzon and its Implementation in Junior High School)

\begin{tabular}{|c|c|c|}
\hline \multirow[t]{2}{*}{$\begin{array}{l}\text { History of } \\
\text { Islamic } \\
\text { Civilization }\end{array}$} & Competence & $\begin{array}{l}\text { Appreciate, imitate, understand and present } \\
\text { the history of the struggle of the Prophet } \\
\text { Mohammed series } \\
\text { Medina, al-Khilafat al-Righteous, Bani } \\
\text { tradition of Islam in the archipelago. } \\
\text { Umayyad, Abbasid, development } \\
\text { andIslamic tradition in the archipelago. }\end{array}$ \\
\hline & $\begin{array}{l}\text { Tazkiyatun } \\
\text { concept nafs } \\
\text { Ahmad karzon }\end{array}$ & $\begin{array}{l}\text { Methods of purification of the soul to } \\
\text { contemplate the life of people - pious } \\
\text { people and learn the story - their story. }\end{array}$ \\
\hline
\end{tabular}

Based on the above, the author tries to make the curriculum development of Islamic religious education and moral junior class VII - IX was developed through the concept of Anas Ahmad Karzon tazkiyatun nafs, and following a review of the competencies developed.

\section{Al-Qur'an}

In the concept of the nafs tazkiyatun Anas Ahmad Karzon, purification of the soul through the Al - Qur'an entry at point Amal Salih influence in tazkiyatun nafs. Understanding Virtue read, memorize, study Al - Qur'an and understand the role of Al - Qur'an in the purification of the soul, this is based on the Hadith of the Prophet

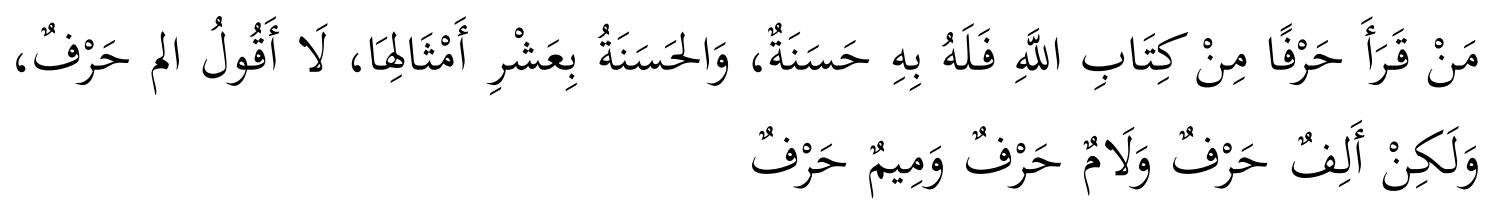

Whoever reads one letter from the Book of Allah, for him a kindness. One goodness will be multiplied ten. I did not say 'Alif Lam Mim' was one letter, however, one letter Alif, Laam Mim one letter and one letter

When students understand the magnitude of the reward of reading the Qur'an then this will affect the student life and a process of purification of the soul for every good thing in the failure by addition will elevate in rank with Allah 粆, Also will remove the person's sin, as in his words, Al - Qur'an Surah Hud: 114

\footnotetext{
${ }^{14}$ Ibid, p. 190
} 


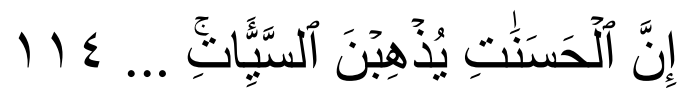

Indeed perbuaan good things were abolished ( $\sin$ ) bad deeds.

2. aqidah

Each building must have foundations. A building constructed and elevated in accordance with the strength and depth of the foundation, to be able to resist the storm.

For a building firm and good spirit, the foundation is a true devotion to Allah, faith in Him, and the religion of truth that He ridai for His servants.

Faith is not just spoken with the tongue only, but it should be planted in the heart and proved it with artificial per-. That's the psychic activity that reaches the recesses of the soul, making it subservient, obedient, surrender, and worship. Growing in faith, will bear fruit was sweet to

Purification of soul and sta Bilitas behavior. Sanctification of Life at the beginning and end can not be separated from the position to-the worship of Allah Ta'ala. He was the one who gave primacy to guide his servants with everything Me-nyucikan their souls if they are sincere and really reaching out to him. His words, in Al - Qur'an Surat an-Nur [24]: 21

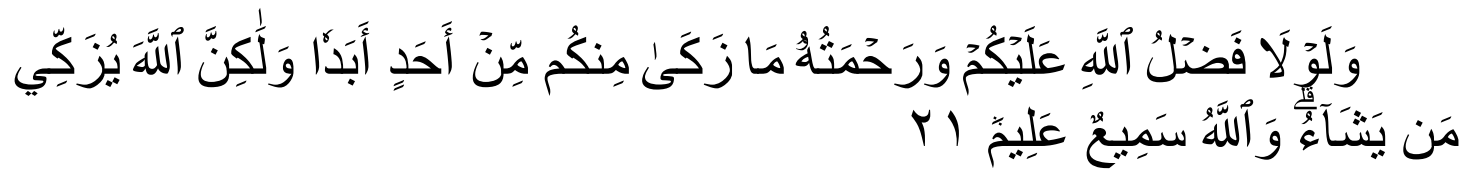

If no bounty and mercy of God to you, then none of you are clean (of indecency and mung-kar) forever. But God purifies whomever he wants. Mahamen-God heard and Aware.

Therefore, the first foundation Soul Sanctification is the Oneness of Allah. That is the meaning of the creed Tauhiid, I testify there is no god but Allah '. Then commitment to the Qur'an and Sunnah, which Me- rupakan demands of the second part of the two sentences creed, that I bear witness that Muhammad is the Messenger of Allah.

Likewise, the other pillars of faith, which became an important foundation for the Soul Turtle cian. And most related to this topic is faith qadhaa 'and Qadar, and remain faithful to the end. 
If the foundation is strong embedded into the soul, the soul of the building will stand firm and privileged, and the tree of faith it will issue a ripe fruit. From here, it is supposed to discuss the basics of faith for the Purification of the Soul. ${ }^{15}$

3. morals

On Moral competence in PAI syllabus mentioned about believe, appreciate, understand the meaning and presents examples of commendable behaviors and act truthfully. In its development include the concept tazkiyatun researchers Anas Ahmad Karzon nafs is by mutual love for Allah, advise each other in goodness and be a good example, with the hope of creating school environments that have a certain atmosphere and civilized.

4. Fiqh

Fiqh competence in the syllabus at PAI mentioned about Running, appreciate, understand and practice the procedures for presenting and purification from impurity of small and large impurity, the obligatory prayers in congregation, prayers Friday, an Islamic prayer in congregation and munfarid, prostration of gratitude, prostration recitations, prostration for forgetfulness, fasting obligatory and sunna, food and beverages is lawful and unlawful, zakat, Hajj and Umrah, the slaughter of animals, sacrifices and aqiqah accordance with the provisions of shari'ah. In its development include the concept tazkiyatun researchers nafs namely Anas Ahmad Karzonunderstand the importance of Ikhlash and Ittiba '(follow) the Prophet Understanding the urgency of Worship and influence in the purification of soul so as to increase appreciation of the wisdom and benefit from every service performed.

5. History of Islamic Education

God The journey of life they meet the books of translation, history, advice, and morals. They are an example that has always been committed to Islam and morals to the morals of the Qur'an al-Karim. People who light their souls, their hearts will be throbbing by the sweetness of faith. They peaked longing to meet Allah swt and attain His Garden. They compete to give and hasten in goodness, and mobilizing their wealth and their lives on

\footnotetext{
${ }^{15}$ Ibid, p. 26
} 
the road preaching to Allah. They are the ones who fulfill their promise to God, and they are the ones who gave the instructions.

These people have undergone Jalan Iman and climbed the ladder Ihsaan. Fighting against their own souls to calm down in obedience to Allah. Free from the shackles of lust and clean from various illnesses. They can achieve this position through a long struggle and determination.

Anyone who wants to undergo a purification method Soul and achieve degreedegree, then consider the course of their lives and reflect on their stories and study sheets - sheets of their charity and directives (advice) them.

It is the biggest motivator for charity. Because sanctification is not just words, he is an action taken and applications that emulate, perceptual speech and honest portrait. Someone will feel kekerdilannya and will make it as mooring eyes, as a preparation for him and adds concern to obey and eliminate laziness and doubt. So that he will always be keen to add to it. ${ }^{16}$

\section{COVER}

Understanding Tazkiyatun nafs by Anas Ahmad Karzon, tazkiyatun nafs is to purify the soul of a bad trend and sin and develop good character in it that can enforce istiqomahnya and reached the degree of ihsan.

Tazkiyatun concept nafs Ahmad Anas Karzon For Science Students include useful, Amal Saleh, Muhasabah and Penance, and make friends with people - the righteous and contemplate the state - keaadaan them. All these concepts seen the influence - influence on Mental Aspects of Sanctification (Tazkiyatun nafs).

Nafs Tazkiyatun Education Implementation in SMP IT Darussofa seen from indicators of success in the study referred to the concept of the nafs tazkiyatun Anas Ahmad karzon shown by, accompanied by the First Science righteous deeds can be seen from the Change Behavior Changes in attitude and inner tranquility in this case in general the students have shown a change from the initial entry into a boarding school until now IT Darussofa junior students. Second Amal Saleh could be seen by students devout soul in worship, which inaccompanied by an improvement in the quality and quantity of the worship of God, timely in conducting worship obligatory and always keep things in sunahkan. In this case a 
significant change to the better, and a few suggestions to make the book daily practice so that students can intstropeksi and focused in doing deeds obligatory or sunnah.third Muhasabah and Repentance seen from a change in attitude, waking up in the third of the night to bermuhasabah and repent and obey the rules of boarding. As the results of the questionnaire showed good results and has been accomplished. Fourth friends with pious people by creating a conducive environment and support each other in goodness. As in the questionnaire that was distributed to 31 students, the results obtained are very good and have done from dicanankan success indicators.

Nafs Tazkiyatun Curriculum Development in Junior High In this study the enrichment curriculum development tazkiyatun nafs refers to competencies in the curriculum syllabus 2013 junior class 7,8, and 9 revised edition 2017 subject of Islamic education and Budi Character. Its development is associated with the concept of the nafs Tazkiyatun Anas Ahmad Karzon, following the syllabus and curriculum development tazkiyatun enrichment nafs. Qur'an The competence of the nafs Tazkiyatun Concepts Understanding Virtue Ahmad karzon ie read, memorize, study Al - Qur'an and understand the role of Al - Qur'an in the purification of the soul.Aqidah Tazkiyatun Concepts Competence of nafs Ahmad karzon Understanding the building foundation is firm and good soul is the true servitude to Allah, faith in Him and the religion of truth that $\mathrm{He}$ ridai for servant - his servant. Morals competence of Concept Tazkiyatun nafs Ahmad karzon Mutual love for God, advise one another in goodness, be a good example, Fiqh competence of Concept Tazkiyatun Ahmad karzon nafs is Understanding the importance Ikhlash and Ittiba '(follow) the Prophet the urgency of Worship and influence in the purification of the soul. History of Islamic Civilization competence of Concept Tazkiyatun nafs Ahmad karzon which method purging of the soul by contemplating the life of people - pious people and learn the story - their story.

\section{REFERENCE}

Al-ghazali, 2007,Ringkasan Ihya' Ulumuddin, terjemah Zeid Husein Al-Hamid, Jakarta: Pustaka Amani.

Al-Jauziah,Ibnu Qayyim, 2001, tazkikiyatun nafs, Solo : pustaka Arafah.

Alsa,Asmadi, 2003, Pendekatan Kuantitatif dan Kualitatif serta Kombinasinya dalam Penelitian Psikologi, Satu Uraian Singkat dan Contoh Berbagai Tipe Penelitian, Yogyakarta: Pustaka Pelajar.

Ariesto Hadi Sutopo dan Adrianus Arief, 2010, Terampil Mengolah Data Kualitatif Dengan NVIVO. Jakarta : Prenada Media Group. 
Mursalin

Arifin, Zainal, 2012, Penelitian pendidikan metode dan paradigma baru, Bandung: PT Remaja Rosdakarya Offset.

Arifin, Zainal, 2013, Konsep dan Model Pengembangan Kurikulum, Bandung : Remaja Rosda Karya.

Arikunto,Suharsimi, 2010, Prosedur Penelitian Suatu Pendekatan Praktik, Jakarta: PT Rineka Cipta.

Derajat, Zakiya, 1991, Ilmu Pendidikan Islam, Jakarta: Bumi Aksara.

Gunawan, Heri, 2014, Pendidikan Karakter: Konsep dan Implementasi, Bandung: CV. Alfabeta.

Gunawan,Imam, 2013, Metode Penelitian Kualitatif: teori dan praktik, Jakarta: Bumi Aksara.

Hayu A'la Aslami, 2016, Konsep Tazkiyatun Nafs Dalam Kitab Ihya Ulumuddin Karya Imam Al-Ghazali, Skripsi pada Fakultas Tarbiyah Institut Agama Islam Negeri Salatiga : Tidak diterbitkan

Hermawan,Asep Herry, 2011,Hakikat Kurikulum dan Pembelajaran, Jurnal Pendidikan Agama Islam, Vol. 2 (No.2), Bandung : UIN.

Humaini, 2008, Konsep Tazkiyatun Nafs dalam Al-Qur'an dan Implikasinya dalam Pengembangan Pendidikan Islam, Skripsi pada Fakultas Tarbiyah UIN Malang : Tidak diterbitkan.

Karzon, Anas Ahmad, 2016, Tazkiyatun Nafs, Jakarta Timur : Akbar Media.

Kholiq,Abdul, 2009, Bimbingan dan Konseling Islam, Yogyakarta : Pura Pustaka.

Kunandiar, 2007, Guru Implementasi Tingkat Satuan Pendidikan (KTSP) dan sukses dalam sertifikasi guru. Rajawali Press. Devisisi buku Perguruan Tinggi. Raja Grapindo Persada.: Jakarta.

Kusuma A, Doni, 2010, Pendidikan Karakter: Strategi Mendidik Anak di Zaman Global, Jakarta: Grasindo.

Langgulung,Hasan, 1986, Manusia dan Pendidikan : Suatu Analisa Psikologi Pendidikan, Jakarta : Pustaka al-Husna.

Majid, 2011, Pendidikan Karakter Presektif Islam, Bandung : PT Remaja Rosdakarya.

Manik,Junaidi, 2012, Konsep Tazkiyatun Nafs Menurut Sa'Id Hawwa (1935 -1989 M), Tesis pada PPS Universitas Muhammadiyah Surakarta : Tidak diterbitkan.

Miles, B. Mathew dan Michael Huberman., 2007, Analisis Data Kualitatif Buku Sumber Tentang Metode-metode Baru. Jakarta: UIP.

Moleong,Lexy, 2006, Metodologi Penelitian Kualitatif, Bandung: PT Remaja Rosdakarya Offset.

Mu'in, Fatchul, 2011, Pendidikan Karakter : Konstruksi Teoretik \& praktik, Jogjakarta: ARRuzz Media.

Mudhofir, Ali, 2011, Aplikasi Pengembangan KTSP dan materi ajar dalam Pendidikan Agama Islam, Jakarta : PT.Rajagrafindo. 
TAZKIYATUN NAFS CURRICULUM DEVELOPMENT IN JUNIOR HIGH SCHOOL (Analysis of Concepts Tazkiyatun Nafs by Ahmad Anas Karzon and its Implementation in Junior High School)

Mujahidin, Endin "Pendidikan Karakter Bangsa Dalam Perspektif Islam (Studi Kritis Terhadap Konsep Pendidikan Karakter Kementerian Pendidikan \& Kebudayaan)", Jurnal Pendidikan Islam, Vol.4 (No.1), Bogor : UIKA, 2015, hlm. 19.

Nasution,S., 2004, Pengembangan Kurikulum, Jakarta : Pustaka Pelajar.

Nata, Abuddin, 2005, Filsafat Pendidikan Islam, Jakarta: Gaya Media Pratama.

Nata,Abudin, 1997,Filsafat Pendidikan Islam, Jakarta: Logos Wacana Ilmu.

Purnomo,Tijan 2013, Pendidikan Karakter Berbasis Tazkiyatun Nafs, Tesis Magister pada PPS Universitas Muhammadiyah Surakarta : Tidak di terbitkan.

Ragan,William B, 1966, Modern Elementary Curriculum, New York : inheart and wiston.

Sudjana,Nana, 1991, Pembinaan dan Pengembangan Kurikulum disekolah, Bandung : Sinar Baru.

Sukmadinata, N.S., 1988, Prinsip dan Landasan Pengembangan Kurikulum, Jakarta: P2LPTK.

Sukmadinata,Nana Syaodih, Metode Penelitian Pendidikan, Bandung: PT Remaja Rosdakarya, 2010 . 